Web Jurnal:

http://ejournal.kemenperin.go.id/jli

\title{
Design of mold press for the manufacturing of silica sand pellet form
}

\section{Perancangan mold press untuk menghasilkan bentuk pelet pasir silika}

\author{
Dedikarni Panuh*1, Rieza Zulrian Aldio ${ }^{1}$, dan Amir Surya Hidayah ${ }^{1}$ \\ 1 Program Studi Teknik Mesin Universitas Islam Riau \\ Jl. Kaharuddin Nasution Km 11 No. 113 Perhentian Marpoyan, Pekanbaru, Indonesia \\ * e-mail: dedikarni@eng.uir.ac.id
}

\begin{tabular}{|c|c|}
\hline INFO ARTIKEL & ABSTRACT \\
\hline Sejarah artikel: & \multirow{7}{*}{$\begin{array}{l}\text { Currently, the ceramic industries is utilizing many natural mineral resources. The purpose } \\
\text { of this study is to design and manufacture the tool; a mold press pellet or silica sand mold } \\
\text { and to obtain the results of silica sand pellets that are affected by varying pressure. The } \\
\text { materials used for the tools were STM A276, Type } 410 \text { steel. ST60 martensite. SS } 400 \\
\text { steel was used to made the round plate at a mold position. This study produced mold with } \\
\text { dimensions of } 25.45 \mathrm{~mm} \text { of diameter, height of } 89 \mathrm{~mm} \text {, volume at } 45.07 \mathrm{~cm}^{3} \text { with a mold } \\
\text { circle area of } 5.06 \mathrm{~cm}^{2} \text { and punch cross-sectional area of } 452.16 \mathrm{~mm}^{2} \text {. The maximum } \\
\text { pressing force on the mold was } 49050 \mathrm{~N} \text {, the normal stress result was } 108.47 \mathrm{MPa} \text {, the } \\
\text { strain value was } 3.8 \mathrm{~mm} / \mathrm{mm} \text {, the modulus of elasticity value was } 28.54 \mathrm{MPa} \text {, the mold } \\
\text { material had a maximum limit of } 812,871 \mathrm{MPa} \text {, indicating that the mold material used } \\
\text { was very good. This silica sand pellet mold produced can be utilized for the development } \\
\text { of fuel cell and composite materials. }\end{array}$} \\
\hline Diter & \\
\hline $\begin{array}{l}\text { 24 Mare } \\
\text { Direvisi }\end{array}$ & \\
\hline nber 2021 & \\
\hline $\begin{array}{l}\text { Diterbitkan : } \\
30 \text { Desember } 2021\end{array}$ & \\
\hline & \\
\hline & \\
\hline
\end{tabular}

Kata kunci:
mold press;
pelet;
pasir silika

\begin{abstract}
ABSTRAK
Industri keramik banyak memanfaatkan sumber daya alam mineral yang terdapat di Indonesia. Tujuan penelitian ini adalah untuk merancang dan membuat alat serta mendapatkan hasil berupa pelet pasir silika. Oleh karena itu sebuah mold press pellet dirancang untuk mendapatkan mold yang berkualitas dengan metode penekanan dingin. Bahan yang digunakan untuk membuat (mold, tuas punch, plat silinder, dan bantalan penekan bawah) adalah ASTM A276, Baja Tipe 410. Baja stainless matrtensit ST60 digunakan untuk membuat (kedudukan punch, dan kedudukan mold). Baja SS400 digunakan untuk membuat (Plat bulat pada kedudukan mold). Dalam penelitian ini dihasilkan mold dengan dimensi atau ukuran diameter 25,45 mm dan tinggi $89 \mathrm{~mm}$. Volume silinder mold adalah 45,07 $\mathrm{cm}^{3}$ dengan luas lingkaran mold 5,06 $\mathrm{cm}^{2}$. Luas penampang punch ialah 452,16 $\mathrm{mm}^{2}$, gaya penekan maksimal pada mold ialah $49050 \mathrm{~N}$. Hasil tegangan normal ialah 108,47 MPa, nilai regangan ialah 3,8 mm/mm, nilai modulus elastisitas ialah 28,54 MPa, bahan material mold yang digunakan memiliki tegangan maksimal sebesar 812,871 MPa, material mold yang digunakan sanagat baik. Berat beban reaksi tumpuan vertikal A dan B ialah $2500 \mathrm{~kg}$ dan momen maksimal yang didapat ialah $-612500 \mathrm{~kg} . \mathrm{mm}$. Cetakan pellet pasir silika yang dihasilkan dapat dimanfaatkan dalam pengembangan bidang fuel cell dan bahan material komposit.
\end{abstract}




\section{Introduction}

There are many clays, feldspar, kaolin dan silica sand distributed in various regions in Indonesia, potentially made them as materials for ceramic industries. Currently, ceramic industries utilizing these natural resources. Silica itself is the most popular material used in highly accurate dimensions of castings at more favorable cost than other materials (Thiel, 2011). Despite its high annual output, silica's utilization rate is still low (Tie, 2012).

Silica is a form of chemical compound with $\mathrm{SiO}^{2}$ molecule, and it can be found in the form of mineral silica which can be obtained from sand mining in various regions. Many investigations regarding silica in the form of silicon nitride in nanorod, nanofiber and nanowire are also conducted in recent years (Bechelany et al 2007; Chaudhari, 2011). Thermo mechanical properties of molded products will improved when reinforced with particle such as silica (Chandran and Waigaonkar, 2017). Silica also used in form of gel as antifungal agent for bamboo (Yang, 2019).

In the industries, silica sand commonly use in glass, cement, ceramic and sandpaper manufacturing. It also commonly used as additive or mixing component in manufacturing processes, high-temperature material (refractory), fiber cement silica board industries and etc. It also used as bearing, mainly known as silica-bearing additive (Pattnaik, 2012). Additionally, silica is preferred because the core removal won't be needing any chemical substances. Thus, silica sand is commonly utilized in research and development of material sciences (Latif et al., 2014).

Another use of silica is known as nano-silica, where it has been used as nano fillers for polymer's coatings to enhance the additive performance (Shi et al. 2013). Other examples are nano silicon dioxide is used in coatings for the preservation of food (Sun et al. 2016). Then nanosilica is also commonly used to prolong fruit shelf life and for the growth of Chinese winter jujube (Kou et al., 2016). Nanosilica/chitosan also used for controlling gray mold of grapes (Youssef et al., 2019; Youssef and Roberto, 2021).

Many research on silica sand in pellet form are conducted, with the silica sand pellet made from mold. The mold design will affect the hardness and form of pellet (Astika et al., 2010). Other experiment involving the silica molds are on the silica stiffness (Lashkaripour, 2003) and sand mold or cores. Pressure on the pellet will affect the porosity and permeability of that pellet (Fadli et al., 2021).

Therefore, there is a need of further research on the designing of silica pellet mold. The mold (with pressing motion process) will be permanent for a repeated uses to save the production cost. The pellets consists of silica sand mixed with bonding material for the test of the silica sand composite's characteristics. The pellet mold also used as samples in pharmaceutical researches, such as tablet and etc.

This tool is expected not only to helps the researchers in material science field, but also those who specialized in renewable energy field, such as fuel cell and solar cell.

\section{Method}

\subsection{Flowchart}

Here are the steps taken in this research, Figure 1 shows the flow of the designing process.

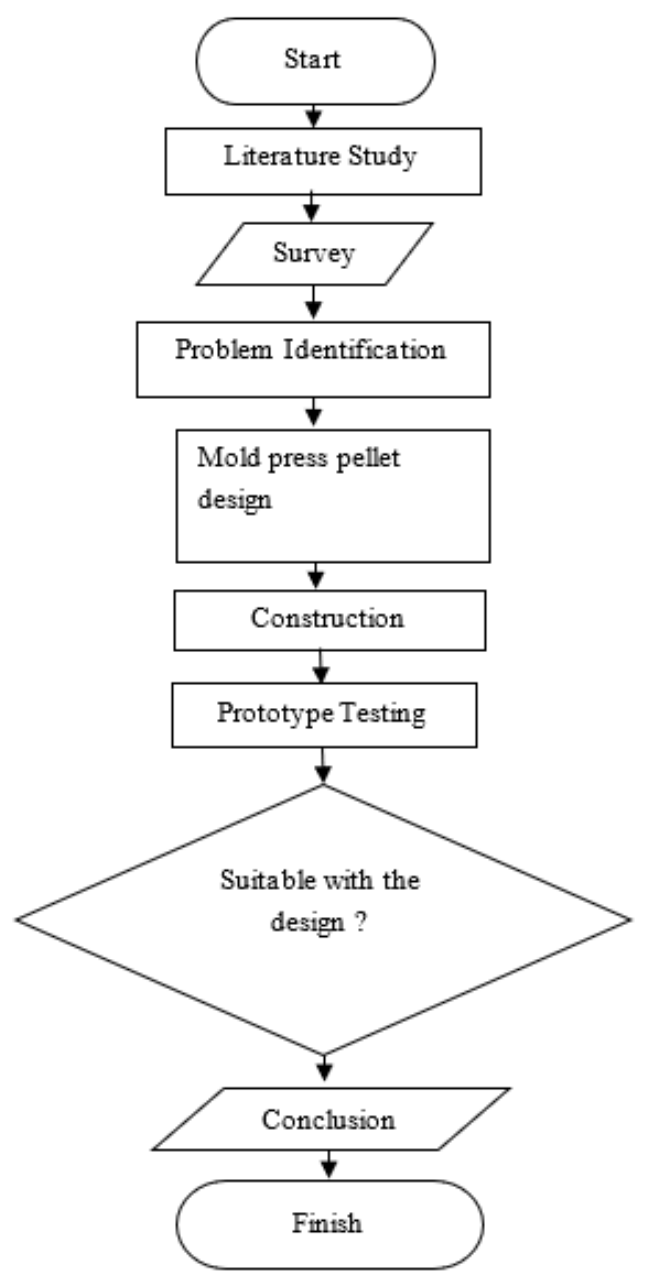

Figure 1. Flowchart

\subsection{Design sketch of mold press pellet}

Figure 2 below shows the design of the mold press pellet.

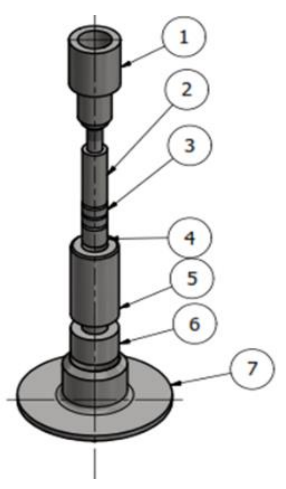

Figure 2. Design of the mold press pellet (1) Punch holder, (2) Punch lever, (3) Upper cylinder plate, (4) Lower cylinder plate, (5) Mold, (6) Lower Pressing pads, (7) Mold holder 


\subsection{Equipment \& materials}

Here are the equipments and materials used for the manufacturing of the mold press pellet (1) Turning machine, (2) Milling machine, (3) Welding machine, (4) Grinding machine, (5) Hydraulic press machine, (6) ST 60 Steel, (7) ASTM A276 type 410 Stainless steel martensite, (8) SS 400 Steel.

\section{Results and discussion}

The results of the mold is based on the dimensions of the mold's parts. Calculation of those parts is a part of the designing process.

\subsection{Mold press pellet specifications}

The Specifications of mold press pellet created in dimensions and materials used in the design with maximum capacity of weight at hydraulic cylinder at $10.000 \mathrm{~kg}$.

Mold press dimensions

$=89 \times 47 \times 25,45(\mathrm{~mm})$

Plate thickness of mold press

$=21,55(\mathrm{~mm})$

Length of torque bar

$=250(\mathrm{~mm})$

Punch dimensions

$=173 \times 33 \times 24(\mathrm{~mm})$

Mold materials

= ASTM A276 Type 410

\subsection{Product design}

On the design of the mold, there is a need for the entrance and exit of the pellet resulted by the press. After the press done and pellet bonded, the pellet will be out and ready for the sintering.

\subsection{The Selection of mold press design}

Figure 3 shows the concept of the mold press. The concept is selected based on the aspect of the easier and lighter pressing process. It also considered how to insert the silica sand into the press mold to get the desired silica sand pellets shape.

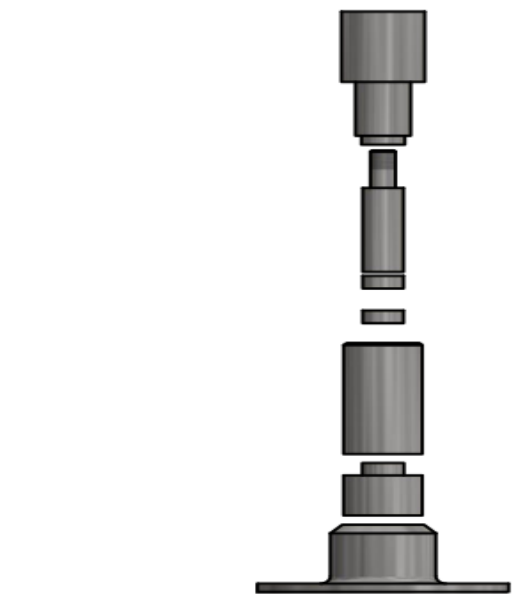

Figure 3. Mold press concept

\subsection{Construction of mold press pellet}

The construction processes are divided into some parts of the mold.

\subsubsection{Punch position}

The finished punch's position is the part that touched directly by the hydraulic press machine. It will received the load or pressure that is given by the hydraulic press, then deliver the pressure onto the mold. The materials used were ST 60 steel.

\subsubsection{Punch lever}

The punch lever is the pressing part of the mold to put pressure on the mold to make silica sand pellets. The material used was Type 410 stainless steel.

\subsubsection{Cylinder plate}

Cylinder plate is the supporting part between the silica sand pellets so that they do not break and to keep them formed as desired. Materials used were ASTM type 410 martensitic steel.

\subsubsection{Mold}

The mold is the main part for making or contain silica sand pellet molds. Materials used were ASTM type 410 martensitic steel.

\subsubsection{Low pressure bearing}

The low pressure bearing is the lower part of the mold, acts as the holder of the received pressure by the hydraulic press. Materials used were ASTM type 410 martensitic steel.

\subsubsection{Mold position}

The position of the finished mold is for the place of the silica sand pellet, pressed in a safe position that would not shift and to avoid unwanted things mixed during pressing. In making this mold position, 2 different materials were used, they are ST 60 steel material for the top cylinder and SS 400 steel for the bottom cylinder plate.

\subsection{Design calculations}

Calculating the volume of the cylinder by :

$$
V=\pi \times r^{2} x t
$$

$\mathrm{V}=$ volume of cylinder $\left(\mathrm{cm}^{3}\right)$

$\mathrm{r}^{2}=$ radius $\left(\mathrm{cm}^{2}\right)$

$\mathrm{t}=$ tube height $(\mathrm{cm})$

Calculation :

$$
\mathrm{V}=\pi \times \mathrm{r}^{2} \times \mathrm{t}
$$




$$
\begin{aligned}
& =3,14 \mathrm{x}(1,27)^{2} \mathrm{~cm} \mathrm{x} 8,9 \mathrm{~cm} \\
& =45,07 \mathrm{~cm}^{3}
\end{aligned}
$$

Area of Circle

$$
\mathrm{A}=\pi \times \mathrm{r}^{2}
$$

$\mathrm{L}=$ Area of circle $\left(\mathrm{cm}^{2}\right)$

$\mathrm{r}^{2}=$ radius $\left(\mathrm{cm}^{2}\right)$

$\mathrm{t}=$ Tube height $(\mathrm{cm})$

with $\mathrm{d}=2,545(\mathrm{~cm})$ :

$$
\mathrm{r}=\frac{D}{2}
$$

$$
\begin{aligned}
& =\frac{2,545 \mathrm{~cm}}{2} \\
& =1,27 \mathrm{~cm}
\end{aligned}
$$

Use formula (3) :

$$
\begin{aligned}
\mathrm{A} & =3,14 \times(1,27)^{2} \mathrm{~cm} \\
& =5,06 \mathrm{~cm}^{2}
\end{aligned}
$$

\subsection{Hydraulic cylinder on the punch}

There are some calculations regarding the punch lever, they are the parts that connected to the hydraulic, shown by Figure 4 below.

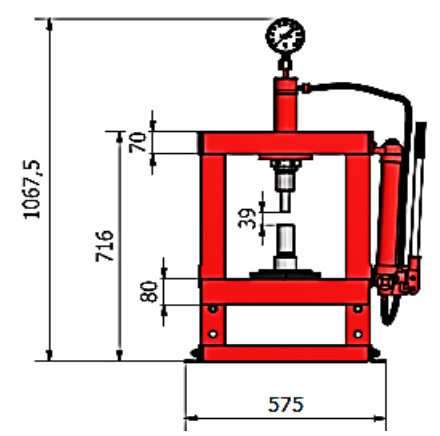

Figure 4. Hydraulic on punch

\subsection{Area of punch}

The formula for the calculation of the area is shown on equation 6 below :

$$
\mathrm{A}=\frac{\pi}{4} \cdot d^{2}
$$

$\mathrm{A}=$ Area of punch (mm2)

$\mathrm{d}^{2}=$ Diameter of punch $\left(\mathrm{mm}^{2}\right)$

Calculation :

$$
\begin{aligned}
A & =\frac{3,14}{4} \cdot 24^{2} \\
& =452,16 \mathrm{~mm}^{2}
\end{aligned}
$$

\subsection{Maximum force on the mold}

For the calculation of the force on the mold, equation 7 below is used :

$$
F \max =\mathrm{m} . g
$$

$$
\begin{aligned}
& \mathrm{F} \max =\text { Force }(\mathrm{N}) \\
& \begin{aligned}
\mathrm{m} & =\text { mass }(\mathrm{kg}) \\
\mathrm{g} & =\text { Gravitation }\left(\mathrm{m} / \mathrm{s}^{2}\right) \\
\text { Calculation }: & \\
\mathrm{F} \mathrm{max} & =5000 \mathrm{~kg} \mathrm{x} 9,81 \mathrm{~m} / \mathrm{s}^{2} \\
& =49.050(\mathrm{~N})
\end{aligned}
\end{aligned}
$$

Maximum value of force could be applied on the mold is $49.050 \mathrm{~N}$.

\subsection{Mechanical properties due to load}

To measure the mechanical properties due to the load applied on the silica sand pellet, there are 3 variable to measure in this case. They are the stress, strain and elasticity. Figure 5 below shows the illustration of stress test.

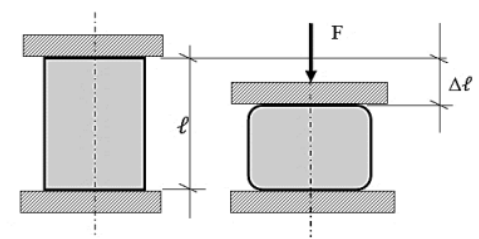

Figure 5. Static press test (Zainal et al., 2018)

\subsection{Normal stress (MPa)}

To measure the normal stress, equation 8 below is used :

$$
\sigma=\frac{\mathbf{F}}{\mathrm{A}}(\mathrm{MPa})
$$

$$
\begin{aligned}
\sigma & =\text { Normal stress }(\mathrm{MPa}) \\
\mathrm{F} & =\text { Load/Force }(\mathrm{N}) \\
\mathrm{A} & =\text { Area of punch applied } \\
\text { Calculation : } & \\
\sigma & =\frac{49050 \mathrm{~N}}{452.16 \mathrm{~mm}^{2}} \\
& =108,47 \mathrm{~N} / \mathrm{mm}^{2} \\
& =108,47 \mathrm{MPa}
\end{aligned}
$$$$
\mathrm{A}=\text { Area of punch applied by the load }\left(\mathrm{mm}^{2}\right)
$$

With the normal stress value of $108,871 \mathrm{MPa}$, the mold should be desirable since it has maximum value of stress at $812,871 \mathrm{MPa}$. The mold materials used can be considered very good.

\subsection{Strain $(\varepsilon)$}

To measure the strain based on the load, equation 9 below is used :

$$
\varepsilon=\frac{\Delta l}{l}
$$

$$
\begin{aligned}
& \Delta \mathrm{l}=l_{0}-l_{1} \\
& \Delta \mathrm{l}=48 \mathrm{~mm}-10 \mathrm{~mm} \\
& \Delta \mathrm{l}=38 \mathrm{~mm} \\
& \varepsilon=\text { Strain }(\mathrm{mm} / \mathrm{mm}) \\
& \Delta \mathrm{l}=\text { Difference of length }(\mathrm{mm}) \\
& l_{0}=\text { Initial length }(\mathrm{mm}) \\
& l_{1}=\text { Final length after test }(\mathrm{mm})
\end{aligned}
$$




$$
\begin{aligned}
& \text { Calculation : } \\
& \begin{aligned}
\varepsilon & =\frac{38 \mathrm{~mm}}{10 \mathrm{~mm}} \\
& =3,8 \mathrm{~mm} / \mathrm{mm}
\end{aligned}
\end{aligned}
$$

With the value of strain at $3,8 \mathrm{~mm} / \mathrm{mm}$ and strain of the mold materials at $43,56 \mathrm{~mm} / \mathrm{mm}$, there was a considerable gap between them.

\subsection{Modulus of elasticity}

Equation 10 below is used to calculate the modulus of elasticity of the mold :

$$
\mathrm{E}=\frac{\sigma}{\varepsilon}
$$

$$
\begin{aligned}
& \mathrm{E}=\text { Modulus of elasticity (MPa) } \\
& \sigma=\text { Normal stress }(\mathrm{MPa}) \\
& \varepsilon=\text { Strain }(\mathrm{mm} / \mathrm{mm}) \\
& \text { Calculation : } \\
& \begin{aligned}
\mathrm{E} & =\frac{108,47 \mathrm{MPa}}{3,8 \mathrm{~mm} / \mathrm{mm}} \\
& =28,54 \mathrm{MPa}
\end{aligned}
\end{aligned}
$$

Value of the modulus of elasticity is $28,54 \mathrm{MPa}$, which making the mold materials was very good since it had maximum stress value at $812,871 \mathrm{MPa}$.

\subsection{Identifying the strength of construction}

After determining the dimensions of the mold, the construction calculations are carried out. Construction calculations including mechanical parts and control parts can be explained, namely:

\subsubsection{Mechanical parts}

The mechanical part is an important part of the silica sand pellet press mold, which consists of the following components:

\subsubsection{Construction (frame)}

The construction of the tool was carried out to determine the strength of the silica sand pellet mold press when it was used as a place and to support the components used.
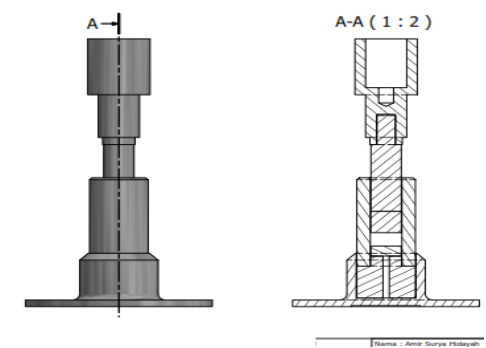

Figure 6. Construction of mold press

So that calculating the construction strength on the silica sand pellet press mold tool, can be seen in the side view, rear view and view of the tool frame. Figure 7 shows the side view of the mold press.
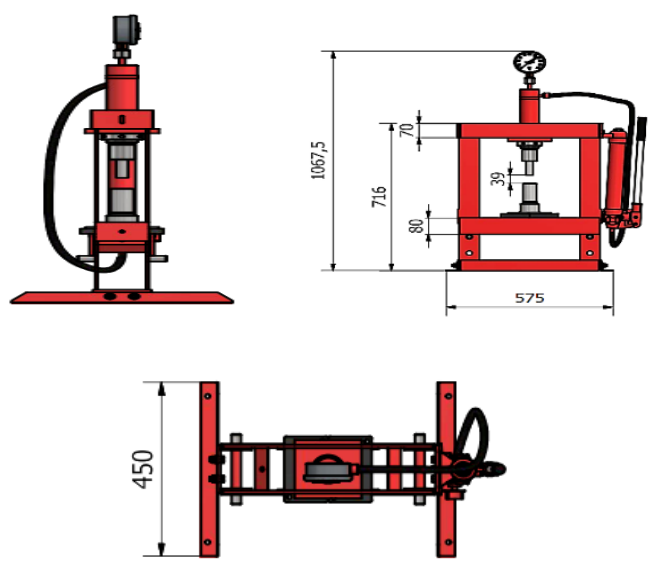

Figure 7. Side, front and top view

As for Figure 7 shows, the front view of mold with dimensions of $490 \mathrm{~mm}$ width and height of $720 \mathrm{~mm}$. Figure 7 also shows the top view of the mold press with height of the hydraulic press at $450 \mathrm{~mm}$. Based on the data in Figure 7 above, the frame construction has a centered reaction on the iron plate. So that it can be calculated and then compared between the amount of load $\mathrm{P}$ on the machine frame. The forces acting on the portal or the intermediate support reaction, the RA vertical support reaction and the RB support vertical support reaction are then calculated to obtain the result.

The frame construction has a centered reaction on the iron plate. So that it can be calculated and then compared between the amount of load $\mathrm{P}$ on the machine frame. The forces acting on the portal or the intermediate support reaction, the RA vertical support reaction and the RB support vertical support reaction are then calculated to obtain the result, namely:

\subsubsection{Vertical support reaction $\mathbf{A}$}

The equation is used to calculate the vertical support reaction A to get the RB calculation results in Figure 8 .

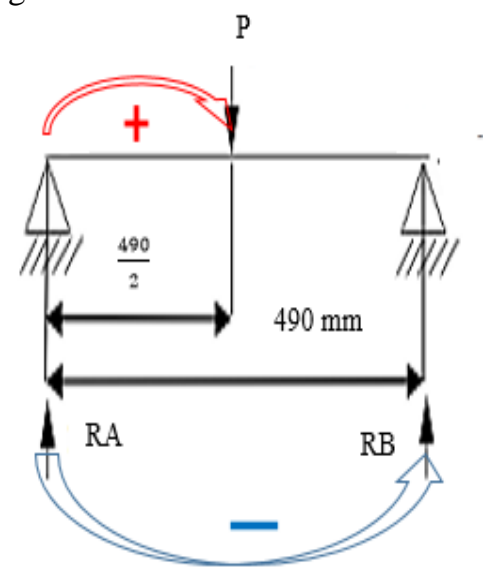

Figure 8. Vertical support reaction A

$$
\begin{gathered}
\Sigma \mathrm{MA}=0 \\
\Sigma \mathrm{MA}=\mathrm{P} \cdot \frac{L}{2}+(-\mathrm{RB}) . \mathrm{L}=0 \\
\mathrm{P} \cdot \frac{L}{2}=\mathrm{RB} \cdot \mathrm{L} \\
\mathrm{P} \cdot \frac{L}{2} \cdot \frac{1}{L}=\mathrm{RB}
\end{gathered}
$$




$$
\mathrm{RB}=\frac{1}{2} \mathrm{P}
$$

$$
\begin{aligned}
& \mathrm{RB}=\text { Reaction support }(\mathrm{kg}) \\
& \mathrm{P}=\operatorname{Load}(\mathrm{kg}) \\
& \mathrm{L} \quad=\text { Length of beam }(\mathrm{mm})
\end{aligned}
$$

Maka:

$$
\mathrm{RB}=\frac{1}{2} \cdot \mathrm{P}
$$

$$
\begin{aligned}
& \mathrm{RB}=\frac{1}{2} \cdot 5000 \mathrm{~kg} \\
& \mathrm{RB}=2500 \mathrm{~kg}
\end{aligned}
$$

Result of the calculation of the vertical support reaction A to get the $\mathrm{RB}$ calculation result is $2500 \mathrm{~kg}$.

\subsubsection{Vertical support reaction $B$}

The equation used to calculate the vertical support reaction $B$ is in Figure 9. The result of the calculation of the vertical support reaction A to get the RA calculation result is $2500 \mathrm{~kg}$. Those are the weight between the vertical support reaction $A$ and the vertical $B$. The load (P) is divided by two, then the calculation results get the support reaction load is $2500 \mathrm{~kg}$.

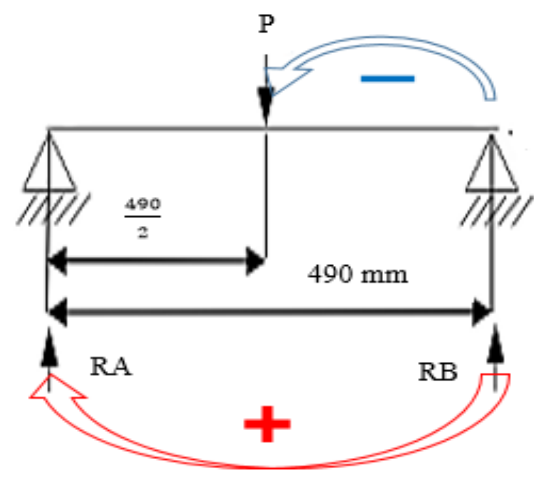

Figure 9. Vertical support reaction B

$$
\begin{gathered}
\Sigma \mathrm{MB}=0 \\
\Sigma \mathrm{MB}=\mathrm{P} \cdot \frac{L}{2}+\mathrm{RA} \cdot \mathrm{L}=0 \\
\mathrm{P} \cdot \frac{L}{2}=\mathrm{RA} \cdot \mathrm{L} \\
\mathrm{P} \cdot \frac{L}{2} \cdot \frac{1}{L}=\mathrm{RA} \\
\mathrm{RA}=\frac{1}{2} \cdot \mathrm{P}
\end{gathered}
$$

$$
\begin{aligned}
& \mathrm{RA}=\text { Reaction support }(\mathrm{kg}) \\
& \mathrm{P}=\operatorname{Load}(\mathrm{kg}) \\
& \mathrm{L} \quad=\text { Length of beam }(\mathrm{mm})
\end{aligned}
$$$$
\text { Maka: }
$$

$$
\begin{aligned}
& \mathrm{RA}=\frac{1}{2} .5000 \mathrm{~kg} \\
& \mathrm{RA}=2500 \mathrm{~kg}
\end{aligned}
$$

\subsubsection{Maximum moment}

Calculating the Maximum Moment on a simple beam with a load centered in the middle part of the beam. A simple beam forces diagram with a centered load can be seen in Figure 10.

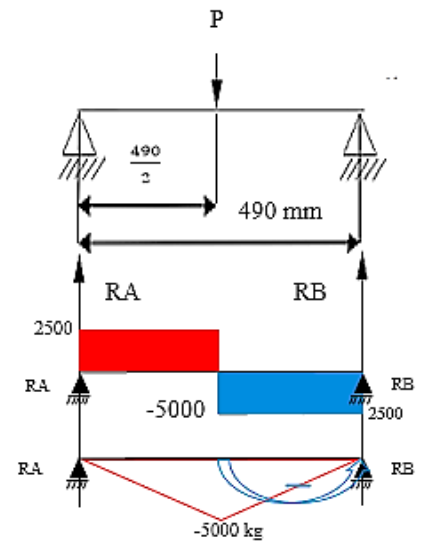

Figure 10. Maximum moment

$$
\begin{aligned}
\operatorname{Mmax} & =-\mathrm{RB} \cdot \frac{1}{2} \mathrm{~L} \\
& \text { Or, } \\
\operatorname{Mmax} & =-\frac{1}{2} \mathrm{P} \cdot \frac{1}{2} \mathrm{~L} \\
\operatorname{Mmax} & =-\frac{1}{4} \cdot \mathrm{P} \cdot \mathrm{L}
\end{aligned}
$$

$$
\begin{array}{lll}
\operatorname{Mmax} & =\text { Max moment } & \text { kg.mm }) \\
\mathrm{P} & =\text { Load } & (\mathrm{kg}) \\
\mathrm{L} & =\text { Beam's length } & (\mathrm{mm})
\end{array}
$$

The calculation :

$$
\begin{aligned}
& \text { Mmax }=-\frac{1}{4} .5000 \mathrm{~kg} .490 \mathrm{~mm} \\
& \operatorname{Mmax}=-612500 \mathrm{~kg} \cdot \mathrm{mm}
\end{aligned}
$$

The result of the calculation of the Maximum Moment on a simple beam with a centered load in the middle of the beam is $-612500 \mathrm{~kg} . \mathrm{mm}$.

\section{Conclusion}

From this study, the materials used are ST60 steel, 410 type of stainless steel and SS400 steel. They are used as the parts on the constructed tools. ST60 used as punch position and mold position. 410 type of stainless steel used as mold, punch, cylinder plate, and bottom pressure bearing, consists of $11.5 \%$ chromium and has good corrosion resistance properties. As for SS400 steel, used as round plate at mold position.

The results of the calculation of the mold press are mold cylinder volume and mold circle area are $45.07 \mathrm{~cm}^{3}$ and $5.06 \mathrm{~cm}^{2}$ respectively. The calculation results obtained on the cross-sectional area of the punch is $452.16 \mathrm{~mm}^{2}$ and the maximum pressure force on the mold press is $49050 \mathrm{~N}$.

The results of the calculation of the mechanical behavior due to static loads, among other things, the normal tension $(\sigma)$ is $108.47 \mathrm{MPa}$, strain $(\varepsilon)$ is $3.8 \mathrm{~mm} /$ $\mathrm{mm}$, the modulus of elasticity (E) is $28.54 \mathrm{MPa}$. The mold material used is more than capable since it has a maximum limit of $812.871 \mathrm{MPa}$. The material for mold used can be considered as very good. 
The result of the weight of the vertical support loads $\mathrm{A}$ and $\mathrm{B}$ is $2500 \mathrm{~kg}$, and the maximum moment result that is obtained is $-612500 \mathrm{~kg} . \mathrm{mm}$.

\section{Acknowledgements}

Special thanks to Lembaga Penelitian dan Pengabdian kepada Masyarakat Universitas Islam Riau (LPPM UIR) for financing this research and also to Faculty of Engineering UIR for supporting and facilitating our research.

\section{References}

Astika, IM., Negara, DNKP, Susantika, MA. 2010. Pengaruh jenis pasir cetak dengan zat pengikat bentonit terhadap sifat permeabilitas dan kekuatan tekan basah cetakan pasir (sand casting). Jurnal Ilmiah Teknik Mesin, Fakultas Teknik Universitas Udayana, 4(2), 132-138.

Bechelany, M., Brioude, A., Bernard, S., Ferro, G., Cornu, D., Miele, P. 2007. Large scale preparation of faceted silicon nitride nanorods from beta silicon carbide nanowires. Nanotechnology, Vol. 18, pp. 1-6

Chandran, V. G. and Waigaonkar, S. D. 2017. Rotational molding of linear low density polyethylene (LLDPE) fumed silica nanocomposites. International Polymer Processing, 32(1), 50-57.

Chaudhari, M.G., Ahmadullah, S.K., Dey, R., Das, G. C., Mukherjee, S. and Mitra, M.K. 2011. Novel techniques for synthesis of silicon nitride nanowires. Advances in Applied Ceramics. Vol. 110, No. 4, pp. 211-214.

Fadli, H., Dedikarni, Yulianto, D. 2021. Pengaruh penekanan pellet silika terhadap porositas dan permeabilitas. Journal of Renewable Energy and Mechanics, Vol. 4 (1), pp 1-6.

Kou, X., He, Y., Li, Y., Chen, X., Feng, Y. and Xue, Z. 2019. Effect of abscisic acid (ABA) and chitosan/nanosilica/sodium alginate composite film on the color development and quality of postharvest chinese winter jujube (zizyphus jujuba mill. cv. Dongzao). Food Chem. 270 385-394.

Lashkaripour, G.R. and Ajalloeian, R. 2003.
Determination of silica sand stiffness. Engineering Geology. Vol. 68(3), 225-236

Latif, C., Triwikantoro, Munasir. 2014. Pengaruh variasi temperatur kalsinasi pada struktur silika. Jurnal Sains dan Seni Pomits, 4-7. doi:10.12962/j23373520. v3i1.5563.

Shi, S.Y., Wang, W., Liu, L.Q., Wu, S.J., Wei, Y.Z. and Li, W.C. 2013. Effect of chitosan/nanosilica coating on the physicochemical characteristics of longan fruit under ambient temperature. J. Food Eng. 118 125131.

Sun, T., Wu, C.L., Hao, H., Dai, Y. and Li, J.R. 2016. Preparation and preservation properties of the chitosan coatings modified with the in situ synthesized nano SiOx. Food Hydrocoll. 54 130138.

Thiel, J. 2011. Thermal expansion of chemically bonded silica sands. AFS Transactions, Vol. 116, pp. 369378.

Tie, S.N., Jiang, Z.Y. and Wang, C.G. 2012. The application research and present development situation of silica fume powder produced from submerged arc furnace smelting ferroalloy. B. Chin. Ceram. Soc. 31 1491-1497

Yang, S., Luo, S., Huang, A., Luo, Y., Li, D., Wu, Y., and Ji, N. 2019. Mold resistance of bamboo treated with copper complexes-grafted silica gel and its microdistribution in treated bamboo. Journal of Wood Science, 65(1).

Youssef, K., de Oliveira, A.G., Tischer, C.A., Hussain, I. and Roberto, S.R. 2019. Synergistic effect of a novel chitosan/silica nanocomposites-based formulation against gray mold of table grapes and its possible mode of action, Int.J. Biol. Macromol. 141 247-258.

Youssef, K., and Roberto, S. R. 2021. Chitosan/silica nanocomposite-based formulation alleviated gray mold through stimulation of the antioxidant system in table grapes. International Journal of Biological Macromolecules, 168, 242-250

Zainal et al., 2018. Pengaruh pembebanan tekan terhadap kekuatan material komposit diperkuat pengaruh pembebanan tekan terhadap kekuatan material komposit diperkuat serat ampas tebu. ISSN 23565438, 9(July), 5. https://doi.org/ISSN 2356-5438. 